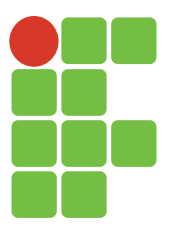

\title{
Probable rainfall in Lambari region, Southern Minas Gerais State
}

Leandro Campos Pinto ${ }^{1}$

Pedro Luiz Terra Lima²

Sílvio de Castro Silveira ${ }^{3}$

Joel Augusto Muniz ${ }^{4}$

Zélio Resende de Souza ${ }^{5}$

Carlos Rogério de Mello ${ }^{6}$

\section{Abstract}

The knowledge of rainfall distribution and behavior at certain areas is crucial for irrigation systems design and management, as well as rainfall tracking regarding soil conservation aspects. Thus, the objective of this research was the comparison and statistical adequacy of probability distribution models applied to probable rainfall studies to determine which probability model is more appropriate to distinct seasons (monthly, fortnightly and every ten days) and to estimate probable rainfall for different probability levels in Lambari region, South of Minas Gerais State, Brazil. Log-normal at 3 parameters and Gamma were the most adequate for monthly and ten-day periods. For fortnight periods, Gamma was the most appropriated, with annual average values of monthly, fortnightly and ten-day period rainfall to $75 \%$ probability levels of $82.4,72.1$, and $42.4 \mathrm{~mm}$, respectively.

Keywords: Probability distribution. Log-Normal. Gamma. Agricultural planning.

\section{Introduction}

Worldwide, at the next 40 years, emerging countries like Brazil are being projected to a higher development, due to its highly competitive agriculture (TOLLEFSON, 2010).

However, economic and technological growth have generated several environmental imbalances, which reflect into several alterations at natural ecosystems. Thus, there is an elevated concern worldwide related to natural resources availability and preservation, especially water, aiming sustainable management.

The knowledge of rainfall behavior and distribution can provide subsidies to determine critical predominant periods at a certain region and to get information to reduce consequences caused by rainfall fluctuations, due to use of irrigation or to implantation of adapted crops to seasonality of this system (ANDRADE et al., 1998; GOMIDE, 1998).

$1 \quad$ Federal University of Lavras, Postdoctoral fellowship. Lavras, Minas Gerais, Brazil. E-mail: leandcampos@yahoo.com.br. Soil Science Department/ UFLA. PO Box 3037, Lavras, Minas Gerais, CEP 37200-000. (corresponding author)

2 Federal University of Lavras, doctoral student. Lavras, Minas Gerais, Brazil. E-mail: pedroterralima@yahoo.com.br. Soil Science Department/ UFLA. PO Box 3037, Lavras, Minas Gerais, CEP 37200-000.

3 Federal University of Lavras, doctoral student. Lavras, Minas Gerais, Brazil. E-mail: silviodecs@gmail.com. Exact Science Department/ UFLA. PO Box 3037, Lavras, Minas Gerais, CEP 37200-000.

4 Federal University of Lavras, professor. Lavras, Minas Gerais, Brazil. E-mail: joamuniz@dex.ufla.br. Exact Science Department/ UFLA. PO Box 3037, Lavras, Minas Gerais, CEP 37200-000.

5 Federal University of Lavras, doctoral student. Lavras, Minas Gerais, Brazil. E-mail: zeliodesouza@yahoo.com.br. Soil Science Department/ UFLA. PO Box 3037, Lavras, Minas Gerais, CEP 37200-000.

6 Federal University of Lavras, professor. Lavras, Minas Gerais, Brazil. E-mail: crmello@deg.ufla.br. Soil and Water Engineering Group, Engineering Department/ UFLA. PO Box 3037, Lavras, Minas Gerais, CEP 37200-000. 
Agriculture in Lambari city constitutes the main economic activity, constituting the main crops grown, coffee, maize, rice, beans and greenery crops.

Soil moisture and available water at plant root zone are highly dependent on local rainfall frequency and intensity, as important as total rainfall quantity at region (SCHIERMEIER, 2008).

Probable rainfall estimation is important to agricultural planning and irrigation systems design aiming to provide additional water to plants (BERNARDO et al., 2005). According to Castro et al. (1994), in Brazil, average rainfall is used on agricultural projects design, which consists in important risk assumed by the farmers.

Several probability distribution models have been used to estimate probable rainfall to different locals and occurrence periods. Among all, stands out Normal (ANDRADE JÚNIOR; BASTOS, 1997; ASSIS et al., 1996), Gamma (ANDRADE JÚNIOR; BASTOS, 1997; ASSIS et al., 1996; RIBEIRO; LUNARDI, 1997; RIBEIRO et al., 2007; RIBEIRO, 2010; RIBEIRO et al., 2013) and Log-Normal (JUNQUEIRA JUNIOR et al., 2007; PINTO et al., 2014; RIBEIRO et al., 2007).

Thus, the objective of this research is: I) study and compare statistical adequacy of probability distribution models applied to probable rainfall studies using Chi-square tests; II) determine which probability model is most adequate to which region and at different seasons (monthly, fortnightly and ten-day period); III) estimate probable rainfall to different probability levels, in Lambari region, south of Minas Gerais State, Brazil.

\section{Materials and methods}

Research data were obtained from rainfall records of weather station in Lambari ( $21^{\circ} 58^{\prime}$ ' ; $45^{\circ} 22^{\prime} \mathrm{W}$ ) operated by Agência Nacional de Águas (ANA), from 1977 to 1998 . Climate at that region is defined as moderate humid subtropical according to Köppen classification and average annual rainfall is about $1500 \mathrm{~mm}$, average temperature being $18^{\circ} \mathrm{C}$ (ANTUNES, 1986).

Figure 1 presents geographic location of Lambari, Minas Gerais State, Brazil.

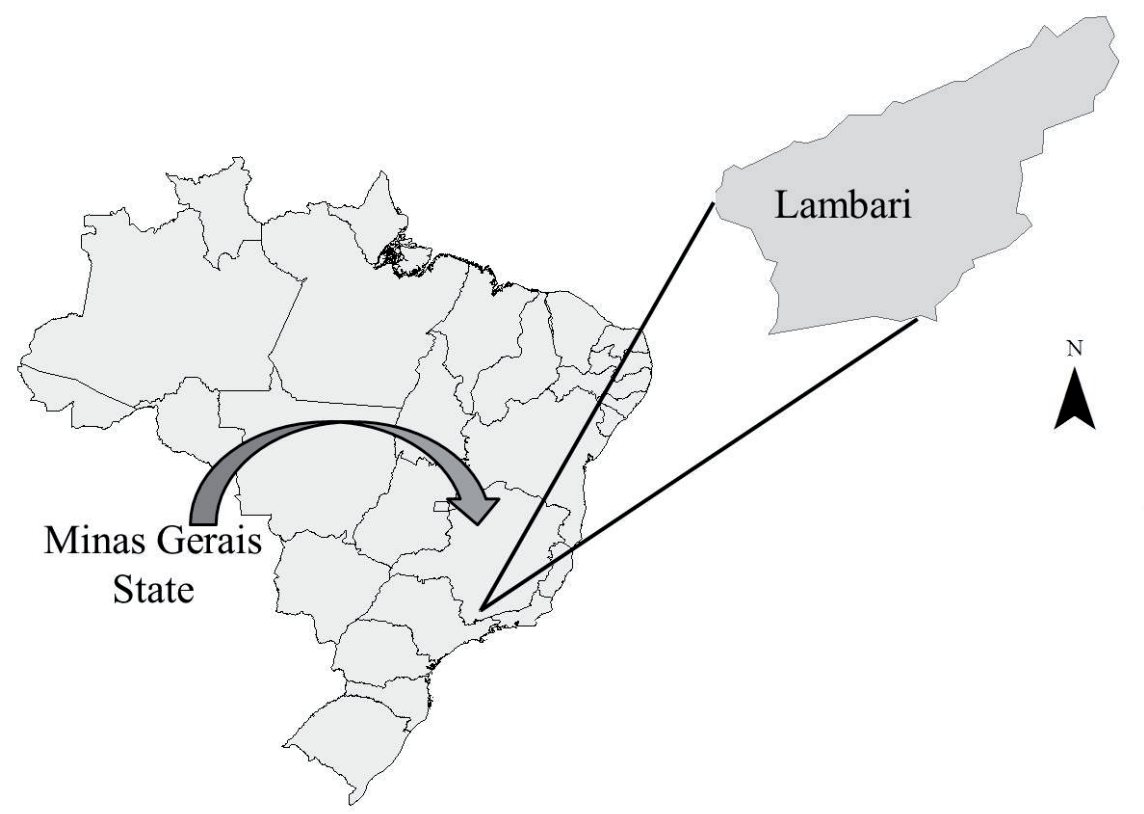

Figure 1. Location of Lambari city, South of Minas Gerais State. 
Thus, 22 years historical series were analyzed. Daily water depths were totalized in annual, monthly, fortnightly (December to March) and ten-day period (December to February) seasons, the following distributions were applied:

a) Log-Normal 2 parameters distribution

This function is described by Probability Density Function (PDF), such as (NAGHETTINI; PINTO, 2007):

$$
\text { PDF : } f(X)=\frac{1}{x \cdot \sigma n \cdot \sqrt{2 \cdot \pi}} e^{-0,5 \cdot\left(\frac{\operatorname{Ln}(x)-\mu n}{\sigma n}\right)^{2}}
$$

where $\mu n$ and on are distribution parameters, corresponding to average and standard deviation of logarithms information. Base equation to hydrological studies, using Log-Normal 2 parameters distribution, is adapted to general equation of Vent e Chow (HAAN, 2002):

$$
X_{R}=e^{\mu n+o n \cdot K_{R}}
$$

Where $X_{T R}$ is the hydrologic variable value (rainfall), associated to return period (RP), and $K_{T R}$ is the reduced variable.

b) Log-Normal 3 parameters distribution

The function has its PDF presented by the following equation:

$P D F: f(x)=\frac{1}{(x-\beta) \cdot \sigma n \cdot \sqrt{2 \cdot \pi}} \cdot e^{0,5\left(\frac{\operatorname{Ln}(x-\beta)-\mu n}{\sigma n}\right)^{2}}$

PDF parameters were estimated by the following equation (NAGHETTINI; PINTO, 2007):

$$
\begin{aligned}
& \beta=\mu n-\frac{\sigma n}{\eta y} \\
& \eta y=\frac{\left(1-\phi^{\frac{2}{3}}\right)}{\phi^{\frac{1}{3}}} \\
& \phi=\frac{\left|-y+\left(y^{2}+4\right)^{0,5}\right|}{2} \\
& y=\frac{n}{(n-1) \cdot(n-2)} \cdot \frac{\sum_{i}^{n}\left(x_{i}-\bar{x}\right)}{s^{3}}
\end{aligned}
$$

Primarily, $y$ is calculated (equation 7) regarding distribution asymmetry. Then " $\varnothing$ " is estimated 
by equation 6 , ny using equation 5 and, based on this last value and on average $(\mu n)$ and standard deviation $(\sigma n)$ of data transformed into logarithms, parameter $\beta$ is estimated by equation 4 . At this situation, base equation to hydrologic variable estimation is demonstrated (HAAN, 2002):

$$
X_{R}=e^{\mu n+K_{R} \cdot \sigma n}+\beta
$$

c) Gamma distribution

Incomplete Gamma distribution is defined, according to Lanna (2001), by an integral equation:

$\Gamma(\alpha)=\int_{0}^{\infty} x^{\nu-1} e^{-x} d x, \quad v>0$

$P(\alpha, x)=\int_{0}^{x} x^{\nu-1} e^{-x} d x$

$P(\alpha, x)=\int_{0}^{x} x^{\nu-1} e^{\frac{-x}{\beta}} d x$

Its PDF can be expressed by Botelho (1989):

$P D F: f(x)=\frac{1}{\beta^{v} \cdot \Gamma(v)} \cdot x^{\nu-1} \cdot e^{\frac{-x}{\beta}}, 0 \triangleleft x \triangleleft \infty$

where $v>0, \beta>0, \Gamma(v)>0$, which $v$ is dimensionless form parameter, $\beta$ is scale parameter and $x$ is random variable (rainfall).

$$
\begin{aligned}
& \text { Parameters } v \text { and } \beta \text { can be estimated by: } \\
& v=\frac{\bar{x}^{2}}{s_{x}{ }^{2}} \\
& \beta=\frac{s_{x}^{2}}{\bar{x}}
\end{aligned}
$$

where $\mathrm{x}$ is arithmetic average of data series and $\mathrm{Sx}$ is data standard deviation of data series. The distributions were adjusted based on the method of moments (NAGHETTINI: PINTO; 2007).

In order to evaluate the adequacy of statistical distribution, at all evaluated periods, it was used Chi-square $\left(\chi^{2}\right)$ tests, at $5 \%$ significance level, such as Ferreira (2005) and Naghettini e Pinto (2007).

Probable rainfall were estimated to each period, using the distribution that fits more periods, at exceedance probability levels of 75,85 and $95 \%$, corresponding, respectively, to return periods of 4, 7 and 20 years. Distribution that presented more adjusts can be stated as most precise to studied situation, according to Marques et al. (2014).

\section{Results and discussion}

Figure 2 presents annual rainfall behavior in relation to average value of Lambari region. Average rainfall of the region is $1,505.00 \mathrm{~mm}$ annually. 


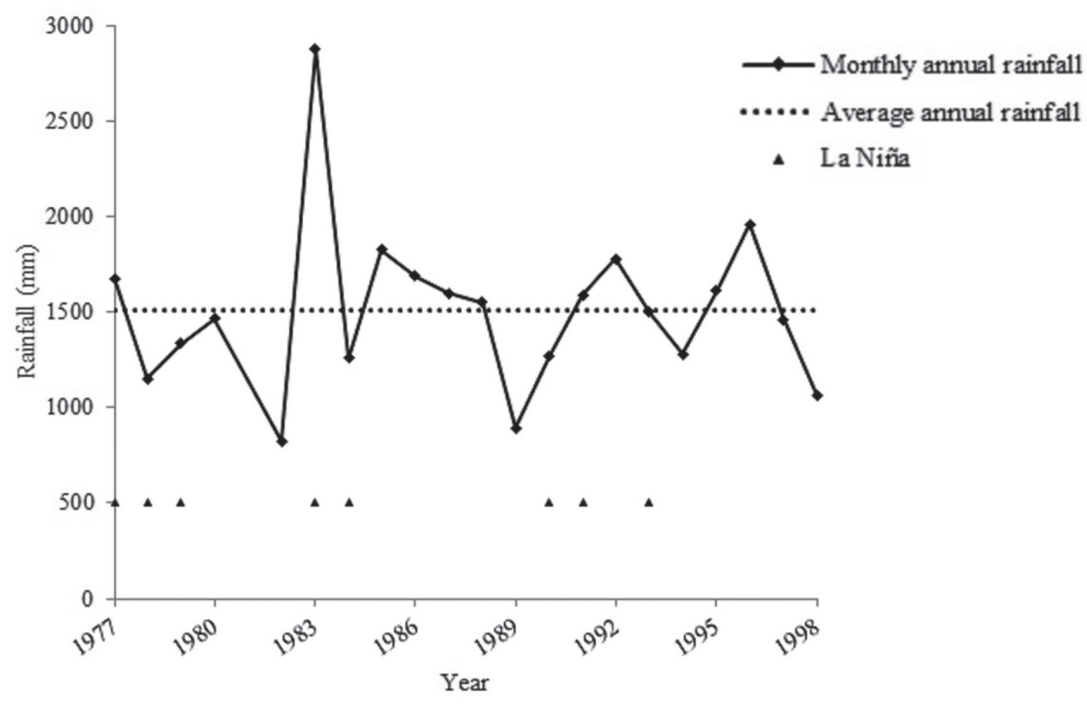

Figure 2. Annually temporal distribution ( $\mathrm{mm}$ ) to Lambari region, MG, Brazil, and its relation to La Niña phenomenon.

Recently and remarkable episodes of La Niña phenomenon occurred in 1984/85, 1988/89 (most intense ones), 1998/99 and 2000/01 years (OLIVEIRA, 2001). Those events match with years of observations which occurred low rainfall in Lambari region. La Niña is characterized by Pacific Ocean water cooling, which changes wind dynamics and consequently spatial distribution of frontal systems that reaches Brazil, making it weakness and reducing rainfall occurrence, especially at northern regions. Thus, the regions are affected by dry periods, at total below average, resulting in low agricultural production times, causing damages to farmers, thus one of the biggest problems resulting in erratic rainfall distribution under influence of global atmospheric circulation phenomenon.

Rainfall variability is also evident over months of the year, splitting on two well-defined seasons at that region: a dry one, from April to September, and a rainy one, from October to March, such as shown on Figure 3.

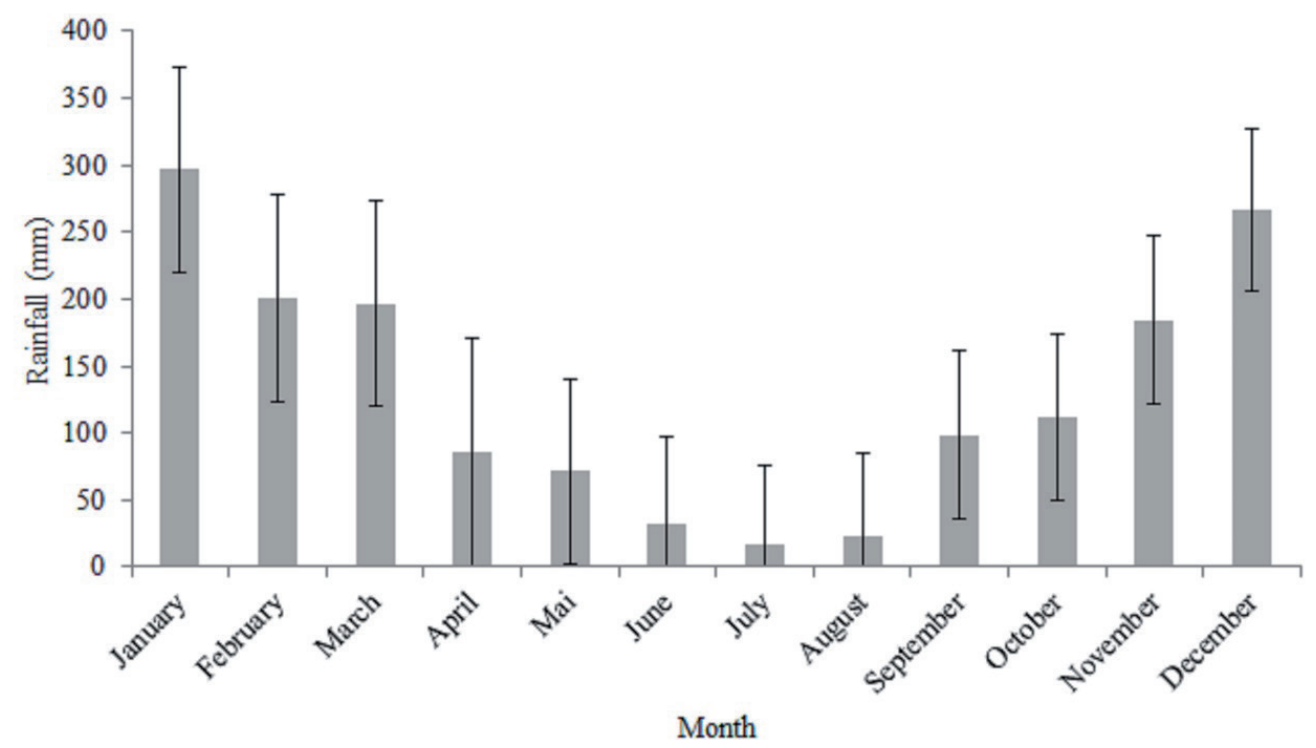

Figure 3. Monthly rainfall distribution $(\mathrm{mm})$ for Lambari region, $\mathrm{MG}$, Brazil. 
Tables 1, 2 and 3 present p-value of statistical adequacy test of Chi-square $\left(\chi^{2}\right)$, to studied probabilities distributions, respectively, at monthly, fortnightly and ten-day periods.

Table 1. P-value of Chi-Square test $\left(\chi^{2}\right)$ to Log-Normal 2 parameters, Log-Normal 3 parameters and Gamma distributions for monthly rainfall in Lambari region, MG.

\begin{tabular}{|lcccccccccccc} 
Period & Jan & Feb & Mar & Apr & May & Jun & Jul & Aug & Sep & Oct & Nov & Dec \\
\hline Log $2 \mathrm{P}$ & $0,691^{\mathrm{A}}$ & $0,504^{\mathrm{A}}$ & $0,691^{\mathrm{A}}$ & $0,229^{\mathrm{A}}$ & $0,040^{\mathrm{N}}$ & $0,367^{\mathrm{A}}$ & $0,018^{\mathrm{N}}$ & $0,002^{\mathrm{N}}$ & $0,029^{\mathrm{N}}$ & $0,691^{\mathrm{A}}$ & $0,810^{\mathrm{A}}$ & $0,948^{\mathrm{A}}$ \\
Log $3 \mathrm{P}$ & $0,195^{\mathrm{A}}$ & $0,504^{\mathrm{A}}$ & $0,691^{\mathrm{A}}$ & $0,367^{\mathrm{A}}$ & $0,040^{\mathrm{N}}$ & $0,948^{\mathrm{A}}$ & $0,504^{\mathrm{A}}$ & $0,948^{\mathrm{A}}$ & $0,504^{\mathrm{A}}$ & $0,142^{\mathrm{A}}$ & $0,810^{\mathrm{A}}$ & $0,229^{\mathrm{A}}$ \\
Gamma & $0,691^{\mathrm{A}}$ & $0,504^{\mathrm{A}}$ & $0,430^{\mathrm{A}}$ & $0,504^{\mathrm{A}}$ & $0,075^{\mathrm{A}}$ & $0,691^{\mathrm{A}}$ & $0,229^{\mathrm{A}}$ & $0,002^{\mathrm{N}}$ & $0,504^{\mathrm{A}}$ & $0,430^{\mathrm{A}}$ & $0,948^{\mathrm{A}}$ & $0,948^{\mathrm{A}}$ \\
\hline
\end{tabular}

Note: $\mathrm{A}$ - adequate distribution, $\mathrm{N}$ - non-adequate distribution.

For the monthly season data (Table 1), adequacy was observed at Log-normal 3 parameters and Gamma in $91,6 \%$ and Log-Normal 2 parameters were adequate in just $66,6 \%$ of cases.

Gamma and Log-normal 3 parameters distributions were appropriate at rainfall representation monthly data, once some authors have determined a better adequacy of Gamma distribution (RIBEIRO et al., 2007; RIBEIRO et al., 2010; RIBEIRO et al., 2013) to some Minas Gerais State regions. Junqueira Júnior et al. (2007) studied probable rainfall to Madre de Deus city, Minas Gerais State, and determined Log-normal 3 parameters distribution as the most adequate to monthly historical series and Gamma distribution as the most adequate to fortnightly and ten-day period seasons.

Analyzing the adequacy of fitted distributions to fortnightly periods (Table 2), the Gamma distribution was more appropriate to represent fortnightly rainfall values to December, January, February and March.

Table 2. P-value of Chi-Square test $\left(\chi^{2}\right)$ to Log-Normal 2 parameters, Log-Normal 3 parameters and Gamma distributions for fortnightly period (December to March) rainfall in Lambari region, MG.

\begin{tabular}{|c|c|c|c|c|c|c|c|c|c|c|c|c|}
\hline \multirow[b]{2}{*}{ Period } & \multicolumn{3}{|c|}{ December } & \multicolumn{3}{|c|}{ January } & \multicolumn{3}{|c|}{ February } & \multicolumn{3}{|c|}{ March } \\
\hline & $\log 2 P$ & $\log 3 P$ & Gamma & $\log 2 P$ & $\log 3 P$ & Gamma & Log 2P & $\log 3 P$ & Gamma & $\log 2 P$ & $\log 3 P$ & Gamma \\
\hline st fortnightly & $0,948^{A}$ & $0,691^{A}$ & $0,948^{A}$ & $0,064^{A}$ & $0,015^{\mathrm{N}}$ & $0,064^{\mathrm{A}}$ & $0,430^{A}$ & $0,367^{A}$ & $0,810^{A}$ & $<0,001^{\mathrm{N}}$ & $0,064^{A}$ & $0,229^{A}$ \\
\hline $2^{\text {nd }}$ fortnightly & $0,078^{A}$ & $0,003^{\mathrm{N}}$ & $0,221^{\mathrm{A}}$ & $0,691^{\mathrm{A}}$ & $0,504^{A}$ & $0,948^{A}$ & $0,606^{A}$ & $0,606^{A}$ & $0,606^{A}$ & $0,367^{A}$ & $0,367^{A}$ & $0,367^{A}$ \\
\hline
\end{tabular}

Note: A - adequate distribution, $\mathrm{N}$ - non-adequate distribution.

Table 2 presents Gamma distribution as adequate to all fortnightly time series by adjusting all periods. Log-Normal 3 parameters were adequate in $87.5 \%$ of cases while Log-Normal 3 parameters were adequate in $75 \%$ of cases.

Table 3 presents adequacy results of probability distributions to ten-day periods from December to February months.

Table 3. P-value of chi-Square test $\left(\chi^{2}\right)$ to Log-Normal 2 parameters, Log-Normal 3 parameters and Gamma distributions for ten-day period (December to February) rainfall in Lambari region, MG.

\begin{tabular}{cccccccccc} 
& \multicolumn{3}{c}{ December } & \multicolumn{3}{c}{ January } & \multicolumn{3}{c}{ February } \\
\cline { 2 - 9 } Period & Log 2P & Log 3P & Gamma & Log 2P & Log 3P & Gamma & Log 2P & Log 3P & Gamma \\
\hline $1^{\text {st ten days }}$ & $0,268^{\mathrm{A}}$ & $0,691^{\mathrm{A}}$ & $0,268^{\mathrm{A}}$ & $0,367^{\mathrm{A}}$ & $0,142^{\mathrm{A}}$ & $0,367^{\mathrm{A}}$ & $0,504^{\mathrm{A}}$ & $0,504^{\mathrm{A}}$ & $0,810^{\mathrm{A}}$ \\
$2^{\text {nd }}$ ten days & $0,367^{\mathrm{A}}$ & $0,367^{\mathrm{A}}$ & $0,367^{\mathrm{A}}$ & $0,810^{\mathrm{A}}$ & $0,015^{\mathrm{A}}$ & $0,691^{\mathrm{A}}$ & $0,015^{\mathrm{N}}$ & $0,268^{\mathrm{A}}$ & $0,229^{\mathrm{A}}$ \\
$3^{\text {rd }}$ ten days & $0,691^{\mathrm{A}}$ & $0,691^{\mathrm{A}}$ & $0,430^{\mathrm{A}}$ & $0,142^{\mathrm{A}}$ & $0,229^{\mathrm{A}}$ & $0,268^{\mathrm{A}}$ & $0,367^{\mathrm{A}}$ & $0,229^{\mathrm{A}}$ & $0,367^{\mathrm{A}}$ \\
\hline
\end{tabular}

Note: $\mathrm{A}$ - adequate distribution, $\mathrm{N}$ - non-adequate distribution.

To ten-day period season (Table 3), it was observed that Log-normal 3 parameters and Gamma distributions were adequate in all cases. Log-Normal 2 parameters were not adequate in the $2^{\text {nd }}$ tendays of February. 
Figure 4, 5 and 6 presents, respectively, monthly, fortnightly and ten-day period probable rainfall associated to probability levels of 75,85 and $95 \%$, based on the better probability distribution, according to Tables 1, 2 and 3. Probable rainfall suggests a water depth to be ensured, safely associated to the probability level used. Probability level increase provided a decrease on probable water depth, once that estimation reliability increase implies on reduction of estimated value. According to Bernardo et al. (2005), when probable rainfall to agricultural purpose is studied, the most recommended probability level is $75 \%$, which means a minimum water depth ensured on three every four years.

At $75 \%$ probability level, it was verified a rainy season with $155 \mathrm{~mm}$ (November to March) and a dry season (April to October) with about $30.6 \mathrm{~mm}$ (Figure 4). Basing on those information, designers will be able to scale an additional irrigation system or even a management of it, given this data, obtained assuming an acceptable and viable probability level, regarding high rainfall variability in Lambari region.

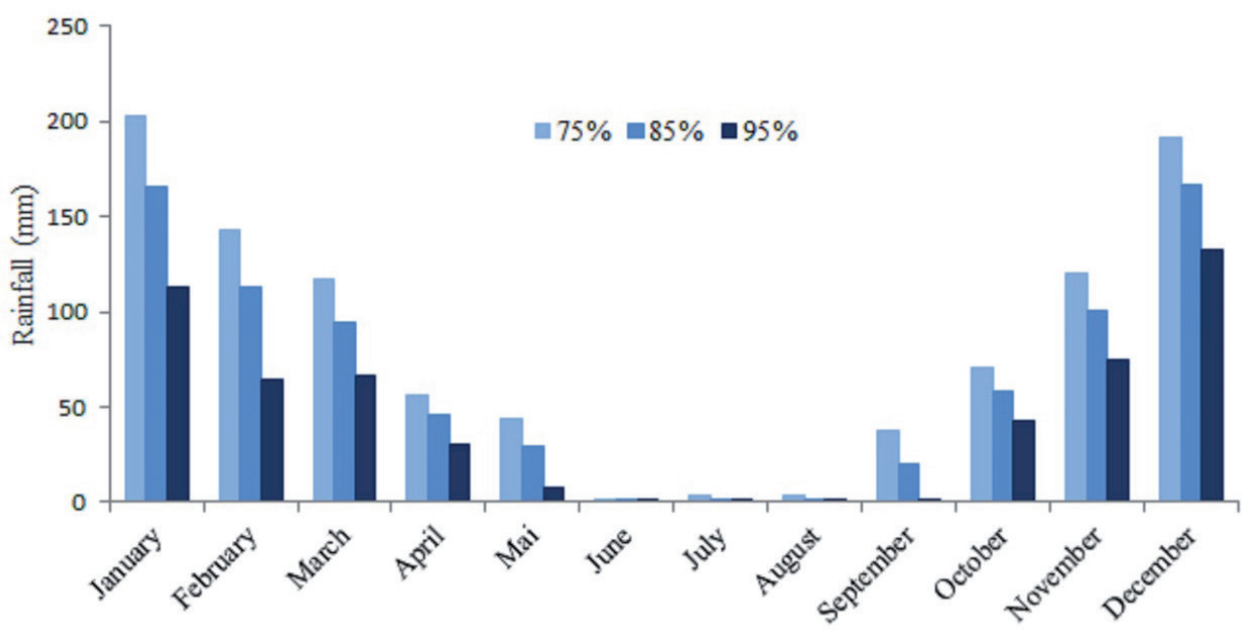

Figure 4. Probable rainfall to Lambari region, MG, Brazil, monthly at 75, 85 and $95 \%$ levels.

In January, at 75\% occurrence probability, it is expected a water depth of $203 \mathrm{~mm}$ (Figure 4). This information is highly important once January presents an average rainfall of $296 \mathrm{~mm}$, the highest among the other months in the year. Also, in that month it is essential to crop developments such as beans, maize, coffee and rice, whereas local farmers plan the planting season to match the crop development stage (plants highest need of water) that month.

Pinto et al. (2014), predicting the probable rainfall of the Aiuruoca River Basin in Minas Gerais State, presented rainfall values of $201 \mathrm{~mm}$ in January, at $75 \%$ probability of occurrence. The Aiuruoca river basin is located in the Alto Rio Grande Basin in the Mantiqueira Range region, from southeastern Brazil. According to Reboita et al. (2010), rainfall events at such in that region are associated with the action of frontal systems (cold fronts) throughout the year, producing significant total amounts of rainfall, especially between December and March.

Based on such analysis, irrigation systems can be designed, just as its management, assuming an acceptable level of probability (JUNQUEIRA JÚNIOR et al., 2007).

Figure 5 shows the probable rainfall during the rainy season splitting into fortnights. Such procedure is important, once it reveals dry seasons occurrence during rainy season. At $2^{\text {nd }}$ fortnight 
occurs the lowest rainfall probability rates during evaluated season, being characterized by highly dry seasons possibility occurrence, which are significant periods of non-rainy days.

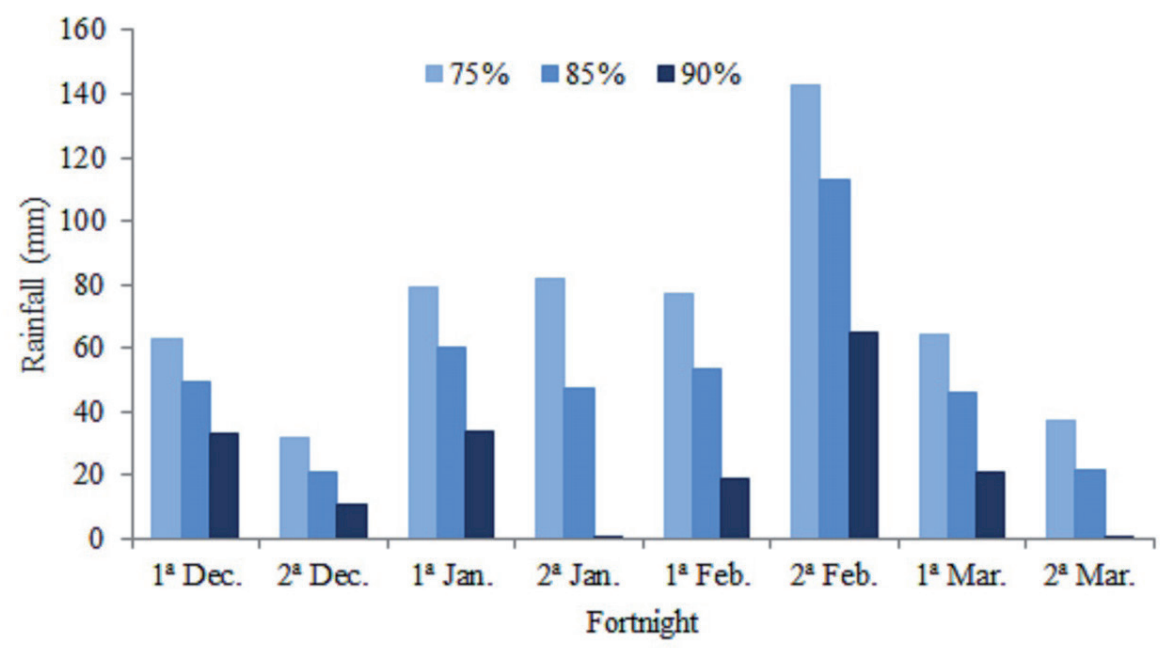

Figure 5. Probable rainfall to Lambari region, MG, Brazil, fortnightly at 75, 85 and $95 \%$ levels, in December, January, February and March.

According to Castro Neto e Silveira (1983), dry seasons are characterized by decrease of rainfall values at a same time period when compared to a season at a year before, during rainy season.

By analyzing probable rainfall (Figure 6 ), it can be verified that at $75 \%$ probability level, a 32 $\mathrm{mm}$ water depth can occur at the $3^{\text {rd }}$ ten-day period of December. When compared to previous tenday period, a probable rainfall decrease can be noted, which indicates a higher dry season occurrence probability between December $10^{\text {th }}$ and $31^{\text {st }}$.

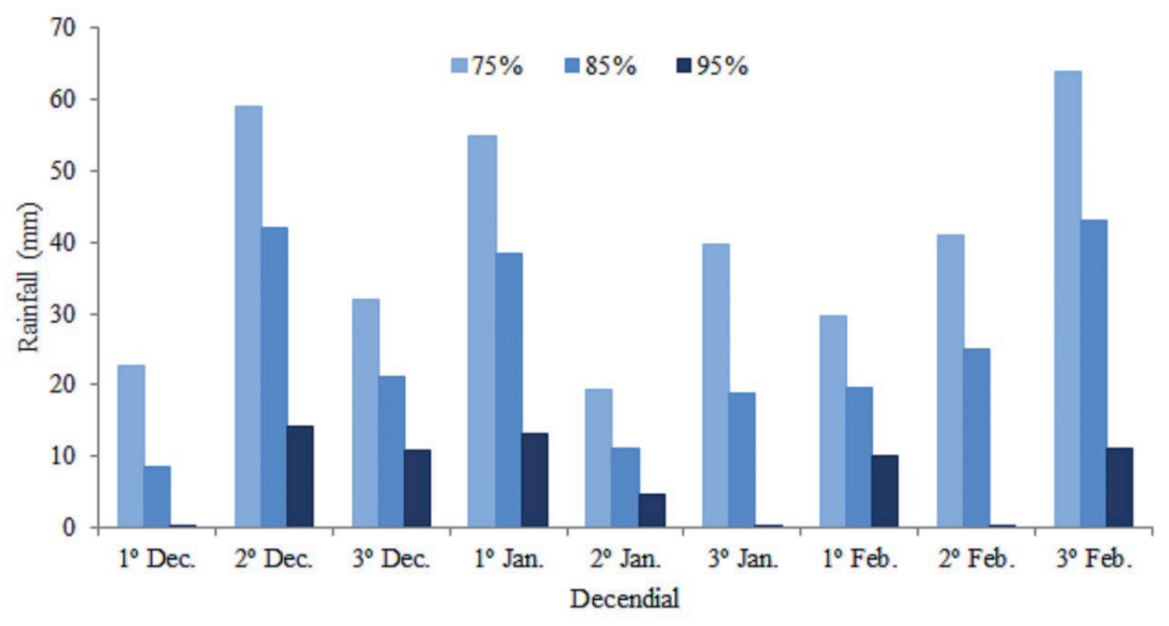

Figure 6. Probable rainfall to Lambari region, MG, Brazil, ten-day period at 75, 85 and $95 \%$ levels, in December, January and February.

Results reveal that rainfall variability, even during rainy station, is concentrated in certain seasons, resulting in an immeasurable loss to the region due to crop production loss, either by irregular 
distribution or by soil damages due to concentrated rainfall.

This research shows that irrigation system implementation may be required in addition to natural rainfall. The use of occurrence probability values of natural rainfall on irrigation systems design can reduce granted flows, facilitating approval of these projects with environmental agencies.

\section{Conclusions}

Gamma and Log-Normal 3 parameters probability distributions presented the best fit to monthIy and ten-day period rainfall historical series to Lambari region, MG, Brazil;

For the fortnightly season, Gamma distribution presented the best fit;

December presents, during rainy seasons, greater irregularity of rainfall;

Annual average values of monthly, fortnightly and ten-day period rainfall to $75 \%$ probability level are 82.4, 72.1 and $42.4 \mathrm{~mm}$, which are high values, once the region is not affected by prolonged dry seasons.

\section{Precipitação provável para a região de Lambari, Sul de Minas Gerais}

\section{Resumo}

O conhecimento do comportamento e da distribuição das precipitações em uma determinada região se torna imprescindível para o dimensionamento e gerenciamento de sistemas de irrigação, bem como o monitoramento do regime pluviométrico quanto aos aspectos de conservação do solo. Nesse sentido, o objetivo deste estudo foi a comparação e adequação estatística de modelos de distribuição de probabilidades aplicados ao estudo da precipitação provável, a determinação de qual modelo de probabilidades é mais adequado para distintos períodos (mensal, quinzenal e decendial) e estimar as precipitações prováveis para diferentes níveis de probabilidade para a região de Lambari, Sul de Minas Gerais. Observou-se que as distribuições de probabilidade Log-Normal 3 parâmetros e Gamma foram as que melhor se ajustaram às séries históricas de precipitação mensal e decendial, e para as séries históricas quinzenais a distribuição Gamma foi superior, sendo os valores médios anuais de precipitação mensal, quinzenal e decendial para o nível de probabilidade de $75 \%$ respectivamente de 82,4, 72,1 e 42,4 mm.

Palavras-chave: Distribuição de probabilidades. Log-Normal. Gamma. Planejamento agrícola.

\section{References}

AGÊNCIA NACIONAL DE ÁGUAS (Brasil) (ANA). HidroWeb: Sistemas de Informações Hidrológicas. Disponível em: <http://hidroweb.ana.gov.br/HidroWeb>. Acesso em: setembro/2013.

ANDRADE JÚNIOR, A. S.; BASTOS, E. A. Precipitação pluviométrica provável em municípios do cerrado piauiense. Teresina: EMPRABA-CPAMN, 1997. 22p. (Documentos, 25).

ANDRADE, C. L. T.; COELHO, E. F.; COUTO, L.; SILVA, E. L. Parâmetros de solo-água para engenharia de irrigação e ambiental. In: FARIA, M. A.; SILVA, E. L.; VILELA, L. A. A.; SILVA, A. M. Manejo de irrigação. Lavras: UFLA/SBEA, 1998. p. 1-132. 
ANTUNES, F. Z. Caracterização climática do estado de Minas Gerais. Informe Agropecuário, Belo Horizonte, v.12, n.138, p.9-15, jun., 1986.

ASSIS, F. N.; ARRUDA, H. V.; PERREIRA, A. R. Aplicações de estatística à climatologia: teoria e prática. Pelotas: Ed. Universitária UFPel, 1996. 161p.

BERNARDO, S.; MANTOVANI, E. C.; SOARES, A. A. Manual de irrigação. Viçosa. UFV, 2005. 611p.

BOTELHO, V. A. Ajuste da distribuição de probabilidade gama aos dados de precipitação para a região de Lavras, MG. 1989. 98 f. Dissertação (Mestrado) Universidade Federal de Lavras, Lavras.

CASTRO NETO, P.; SILVEIRA, J. V. Precipitação provável para Lavras-MG, baseada na função de distribuição de probabilidade gama III: períodos de 10 dias. Ciência e Prática, Lavras, v. 7, n. 1, p. 58-65, 1983.

CASTRO, L. H. R.; MOREIRA, A. N.; ASSAD, E. D. Definição e regionalização dos padrões pluviométricos dos cerrados brasileiros. In: Assad, E.D. (coord.) Chuvas no cerrados: análise e espacialização. Brasília: Embrapa, CPAC; Embrapa, SPI, 1994. p.13-23.

CHOW, V. Handbook of applied hydrology. New York: McGraw-Hill Book, 1964. Paginação irregular. FERREIRA, D. F. Estatística básica. Lavras: UFLA, 2005. 654 p.

FRIZZONE, J. A. Análise de cinco modelos para cálculo da distribuição de precipitação na região de Viçosa, MG. 1979. 100 f. Dissertação (Mestrado) Universidade Federal de Viçosa, Viçosa.

GOMIDE, R. L. Monitoramento para manejo da irrigação: instrumentação, automação e métodos. In: FARIA, M. A.; SILVA, E. L.; VILELA, L. A. A.; SILVA, A. M. Manejo de Irrigação. Lavras: UFLA/SBEA, 1998. p. 133-238.

HAAN, C. T. Statistical methods in hydrology. 2.ed. Ames: The lowa State University, 2002. 377 p. JUNQUEIRA JUNIOR, J. A.; GOMES, N. M.; MELLO, C. R.; SILVA, A. M. Precipitação provável para a região de Madre de Deus, Alto Rio Grande: modelos de probabilidades e valores característicos. Ciência e Agrotecnologia, v. 31, p. 842-850, 2007.

LANNA, A. E. Elementos de estatística e probabilidade. In: TUCCI, C. E. M. Hidrologia: ciência e aplicação. 2. ed. Porto Alegre: ABRH; UFRGS, 2001. p. 79-176.

MARQUES, R. F. P. V.; DE MELLO, C. R.; SILVA, A. M.; Franco, C. S.; OLIVEIRA, A. S. Performance of the probability distribution models applied to heavy rainfall daily events. Ciência e Agrotecnologia, v. 38, p. 335-342, 2014.

NAGHETTINI, M.; PINTO, E. J. A. Hidrologia Estatística. Belo Horizonte: CPRM, 2007. 552p.

OLIVEIRA, G. S. O EI Niño e Você - o fenômeno climático. São José dos Campos, SP: Editora Transtec -, março de 2001.

PINTO, L. C.; LIMA, P. L. T.; SOUZA, Z. R. Maximum discharge and probable rainfall at Aiuruoca basin, Minas Gerais State. Revista Ambiente e Água, v. 9, p. 203-211, 2014. 
Schiermeier, Q. Water: A long dry summer. Nature, v. 452, p. 270-273, 2008.

REBOITA, M. S.; GAN, M. A.; ROCHA, R. P.; AMBRIZZI, T. Regimes de precipitação na América do Sul: uma revisão bibliográfica. Revista Brasileira de Meteorologia, v. 25: p. 185-204, 2010.

RIBEIRO, A. M. A.; LUNARDI, C. A precipitação mensal provável para Londrina, PR, através da função gama. Energia na Agricultura, Botucatu, v.12, p.37-44. 1997.

RIBEIRO, B. T.; AVANZI, J. C.; MELLO, C. R.; LIMA, J. M.; SILVA, M. L. N. Comparação de distribuições de probabilidade e estimativa da precipitação provável para a região de Barbacena, MG. Ciência e Agrotecnologia, v. 31, p. 1297-1302, 2007.

RIBEIRO, B. T. Probable Monthly Rainfall for Machado county, South Minas Gerais State. Revista Agrogeoambiental, v.2 n.1, 2010.

RIBEIRO, B. T.; FERREIRA JÚNIOR, D. C.; SILVA, C. R. 10-day probable rainfall for Uberlândia, Minas Gerais State, Brazil. Bioscience Journal, Uberlândia, v. 29, n. 3, p. 536-542, May/June 2013.

TOLLEFSON, J. The global farm. Nature, v.466, p.554-556, 2010.

VILLELA, S. M.; MATTOS, A. Hidrologia aplicada. São Paulo: McGraw-Hill do Brasil, 1975. 250 p.

\section{Histórico editorial}

Submetido em: 10/12/2013

Aceito em: 08/12/2014 